\title{
A Non-Parametric Comparison Among Firms' Income Statement-Based And Balance Sheet-Based Performance
}

Merwe Oberholzer, North-West University, Potchefstroom, South Africa

\begin{abstract}
The purpose of the study is to create an income statement-based and a balance sheet-based data envelopment analysis (DEA) model, and to demonstrate these models on Johannesburg Stock Exchange (JSE) listed firms and to compare the technical and scale efficiencies of firms among the two models. A convenience sample of 51 JSE-listed industrial companies over a three year period was selected. The practical value of this modeling exercise is that corporate managers can become conscious that, although the income statement and balance sheet performances tend to be related, there is evidence of a significant gap between firms performance according to these measurements.
\end{abstract}

Keywords: Balance Sheet; Data Envelopment Analysis; Income Statement; Statement of Financial Position

\section{INTRODUCTION}

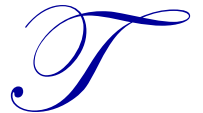

he primary objective of accounting is the provision of the basic answer about a firm's financial performance, communicated to users by means of financial statements (Short et al., 2011). Financial ratio analysis is a well-known method to provide different answers in relation to a firm's performance, but a weakness thereof is that the literature cannot agree upon the relative importance of the different ratios, and it is only appropriate if firms focus on a single input to produce a single output (Chen, 2002). To overcome this weakness, quantitative data, taken from the financial statements, are modeled by means of data envelopment analysis (DEA), which is a non-parametric method using linear programming that computes a comparative ratio of multiple outputs to multiple inputs for each firm, which is reported as the relative efficiency score (Gattoufi et al., 2007; Avkiran, 1999). In this study, modeling is done to determine the relative financial performance of selected firms listed on the Johannesburg Stock Exchange (JSE). The focus is on the separate performance in the statement of comprehensive income (income statement) and the statement of financial position (balance sheet), which aim to report a firm's profitability (revenue - expenses) and solvency (equity = assets liabilities) performance, respectively (Short et al., 2011; Myburg et al., 2011). Therefore, the importance of the study is that it provides a single aggregated answer regarding to multiple inputs and multiple outputs of the income statement performance and balance sheet performance of firms, respectively. The results of this study are important to corporative managers to become conscious that there is possibly a gap between their income statement performance and balance sheet performance that will help to reveal where improvement is needed.

Many previous studies have used DEA to determine the relative efficiencies of firms that are listed in one or another index (Alvandi et al., 2013 (between 63 to 142 Tehran Stock Exchange companies per year for 10 years); Frijns et al., 2012 (unknown number of companies from 1988-2007 on the NYSE, AMEX and Nasdaq); Oberholzer, 2012a (55 JSE companies over a five-year period); Ho \& Oh, 2010 (31 listed US internet companies); Wang et al., 2010 ( 23 companies in the printed circuit board industry); Edirisinghe \& Zhang, 2010 (827 companies on S\&P); Ho et al., 2009 (27 US online-listed companies); Edirisinghe \& Zhang, 2007 (230 US technology industries); Luo, 2003 (245 large banks); Seinford \& Zhu, 1999 (55 US commercial banks)). The above-mentioned studies used various input and output variables and all of them used a combination of accounting-based income statement and balance sheet data, market-based indicators and other data such as number of employees. The studies of Seinford and Zhu (1999), Luo (2003), Ho et al. (2009) and Wang et al. (2010) used two-stage DEA models where the first stage 
estimates operational efficiency and the second stage marketability efficiency. None of the studies investigated separate income statement-based and balance sheet-based models; therefore, the research question is: What is the difference between firms' efficiencies based on income statement and balance sheet data? Studies that are closely related to this study, where exclusively income statement and balance sheet data were used in DEA models, are Hassan Al-Tamimi and Lootah (2006) and Oberholzer et al. (2010). These two studies are distinct from this one as they investigated bank performance and used variables such as interest- and non-interest income, loans and deposits in their DEA models.

The purpose of the study is twofold; firstly, to make use of previous literature to create an income statement-based and a balance sheet-based DEA model; and secondly, to demonstrate the models on JSE-listed firms and to compare the technical and scale efficiencies of firms between the two models. Following the abovementioned studies, DEA was also used since it can overcome the problem of weighting when a number of financial performance indicators are used (Munksgaard et al., 2005) and it lends itself to aggregate the performance into a single measure where multiple inputs and multiple outputs are used (Coelli et al., 2005).

A convenience sample of 51 JSE-listed industrial companies over a three-year period, from March 2011 to February 2013, was selected. This study focused on technical and scale efficiency, respectively, where technical efficiency indicates how well inputs are converted into outputs, while scale efficiency estimates whether a firm operates on a scale that maximizes productivity (Tchereni et al., 2012; Murthy et al., 2009). The arguments of the study are firstly, focusing separately on only income statement and balance sheet data, the internal performance of a firm can be aggregated into these two single factors, which will provide a trustworthy indication of how well the management of a firm performs, because no market values, of which managers have no or little control, are included in these factors. The second argument is that firms are probably not performing equally from an income statement perspective versus a balance sheet perspective. Using separate models for income statement and balance sheet data will support managers to detect more precisely where improvement is needed. This study contributes to the literature by proposing income statement-based and balance sheet-based DEA models where firms' performances are compared using the results of the models. The importance of the contribution is, by estimating technical efficiency, an answer is provided on how well managers of firms perform to convert inputs such as costs and equity into outputs such as profits and equity growth, respectively. Estimating scale efficiency, an answer is provided as to what levels of inputs should be used by firms to operate on a scale that maximizes productivity.

The rest of the paper evolves as follows: The next section is a literature review, followed by a section that explains the theory (mainly DEA) and a section that explains the method of the study. The results are revealed and discussed in the next section and the study is concluded in the final section.

\section{LITERATURE REVIEW}

The reason for exploring related prior literature is to gain some insight in order to create suitable DEA models for this study, i.e. to find a sensible combination of input and output variables. In order to determine company efficiency, Seinford and Zhu (1999), Luo (2003) and Lo and Lu (2006) all used a two-stage DEA model where the inputs of the first stage are employees, total assets and equity and the outputs are revenue and profit. The outputs of the first stage automatically form the inputs of the second stage, where the outputs are market value, stock price and earnings per share. In other words, the first stage measures operational efficiency, while the second stage measures marketability efficiency. Ho and Oh (2010) investigated the selection of Internet stocks and used a similar DEA model with total assets, number of employees and operating expenses as input variables and revenue and net income as the output variables for the first stage.

Oberholzer (2012a) used a DEA model, where sales value, market value of shareholders' interest and dividend payouts are the output variables. The inputs are total expenditure, tangible assets and book value of shareholders' interest. The results of this model provide an aggregated measure of the operating efficiency (sales opposed to the input of scarce resources), profitability efficiency (sales opposed to total expenditure), and marketability efficiency (market value of shareholders' interest and dividends opposed to the book value of shareholders' interest). 55 companies were investigated over a five-year period to determine the relationship between companies' technical efficiencies that are compared with the accounting-based profitability ratios in the Du Pont Analysis and several market-based ratios. 
Frijns et al. (2012) used two DEA models where total sales and market value of equity are the output values, respectively. The inputs of the first model include assets (broken up into two values, i.e. net property, plant and equipment (NPPE) and total assets - NPPE), costs (broken up into two values, i.e. cost of goods sold and selling, general and administrative expenses) and capital expenditure. The inputs of the second model include NPPE, total long-term debt, book value of equity, capital expenditure and selling, general and administrative expenditure. These efficiencies were compared to market return as calculated by CAPM, Fama and French's three-factor model and Carhart's four-factor model. The study concluded that, even after controlling for risk factors, companies' efficiency plays an important role in asset pricing.

Edirisinghe and Zhang (2007) identified 18 ratios spread over six categories, namely profitability (return on equity, return on assets, profit margin and earnings per share), asset utilization (receivables turnover and asset turnover), liquidity (current ratio, quick ratio and debt to equity ratio), leverage (leverage ratio, solvency ratio-I and solvency ratio-II), valuation (price to earnings and price to book ratios) and growth (revenue growth rate, net income growth rate and earnings per share growth rate). Edirisinghe and Zhang (2010) used this as a basis for a DEA model and argue that profitability, valuation and growth can only be used as output variable and that asset utilization, liquidity and leverage can only be used as input variables for the DEA model.

Ho et al. (2009) developed a two-process DEA model. The first process consists of a two-stage DEA model, where the first stage measures efficiency, using total assets, total equity and operating expense as input variables with revenue and gross profit as output variables. These outputs formed the inputs of the second stage, which measures effectiveness, with outputs being the net income and earnings per share. The second process used Beta and book value to market value as input variables and rate of return as the only output variable. The DEA efficiencies of 27 companies were then compared to the traditional measure of return on equity.

Wang et al. (2010) used the grey relation analysis to support the selection of input and output variables for their DEA model. They also used a two-stage model, where the first measures production efficiency with current assets, machine plant and total assets as the financial factor and capacity as the operation factor. The outputs are long-term liabilities (financial) and turnout (operation). The outputs for the second stage, measuring marketing efficiency, consist of earnings before tax (financial) and sales volume (operation).

Alvandi et al. (2013), in their first DEA portfolio, used model stock price and enterprise value per share as inputs and book value per share, dividend per share and earnings before interest and tax per share as output variables, which can be interpreted as a pure composite value. In their second DEA model, they also added momentum as an output variable.

To summarize, the literature proposes the following aggregated inputs for a single stage or first-stage DEA model, namely assets, equity, expenditure, leverage and liquidity. Outputs for a single stage or second stage DEA model are revenue, profit, valuation and growth. For the purpose of this study, valuation will be excluded since it has much to do with the market expectation of investors of which managers have little or no control. The remaining elements will be used in the income statement-based and balance sheet-based DEA models to determine the efficiency how expenses (input) are converted into revenue, liquidity and profits (outputs) and how assets, equity and leverage (inputs) are converted into growth (output), respectively. From an income statement perspective, inputs should be expenses, which can be broken up into different components, and outputs should be revenues and one or more forms of profit. Although Edirisinghe and Zhang (2010) identified liquidity as an input (for example current-, quick- and debt to equity ratios), it is also possible to accommodate it as an income statement output variable. For example, earnings before interest and taxes, after depreciation and amortization (EBITDA), which is a measure of 'cash profit', since this is an accounting measure of operating cashflow and avoids contaminating the results by the effects of gearing (Correia et al., 2011).

From a balance sheet perspective, inputs should be equity, total assets and leverage. Note that the value of total assets used in this study includes intangible assets to account for the size of companies that own non-monetary assets without physical substance, such as intellectual or human capital. The two inputs, equity at book value together with total assets also represent leverage (for example debt/equity ratio (Correia et al., 2011)). The balance sheet-based output consists of growth. Referring to the inputs, it is sensible to determine the growth in the book 
value of equity and total assets. Regarding to the growth in equity, it should be borne in mind that the reward that investors get from buying shares in a company is measured by the cash component and the value component, which are the dividend payouts and the growth in the market value of the shares, respectively (Arnott \& Asness, 2003). Therefore, dividends should also be regarded as an output.

\section{THEORY}

The argument of the study is that evaluating income statement and balance sheet data separately will be helpful to managers to detect more precisely where improvement is needed. DEA can assist in this evaluation process, since multiple input and multiple output variables can be accommodated.

\section{Data Envelopment Analysis}

DEA is a non-parametric linear programming technique that measures the relative efficiency of a comparative ratio of outputs to inputs for a particular decision-making unit (DMU) (Ray (2004). (Non-parametric measure means "the branch of statistics that studies data measurable on an ordinal or nominal scale, to which arithmetic operations cannot be applied" (Collins English Dictionary, 2003)). In other words, DEA compares the efficiency how the same multiple inputs and the same multiple outputs are converted by a DMU, relative to other competing DMUs in the sample (Liu \& Wang, 2009; Min et al., 2009). The fundamental assumption of DEA is that if a DMU is capable of producing $Y(\mathrm{~A})$ units of output with $X(\mathrm{~A})$ inputs, then other DMUs should also be able to do the same if they were operating efficiently. The fundamental objective of the DEA modeling exercise is to find the 'best' virtual DMU for each real DMU and then to compare the DMU to its best virtual DMU in order to determine its efficiency. Analyzing the efficiency of a number of DMUs requires a formulation of a linear programming problem for each DMU to find the best virtual DMU (Anderson, 1996).

The focus of this study is on technical and scale efficiency (TE and SE). As mentioned, technical efficiency is an indication of how well inputs are converted into outputs, while scale efficiency estimates whether a DMU operates on a scale that maximizes productivity. DEA can determine efficiencies from an input-orientated (input minimization) or output-orientated (output maximization) point of view (Coelli et al., 2005). Furthermore, analysts typically choose between using constant return to scale (CRS) or variable return to scale (VRS) (Avkiran, 1999). Charnes et al. (1978) developed the CCR ratio definition, which is based on the assumption of CRS (Alvandi et al., 2013). Using CRS, a DMU is automatically considered fully scale efficient (Coelli et al., 2005; Theunissen, 2012), because it implies a proportionate rise in outputs when inputs are increased, or in other words, a DMU's efficiency is not influenced by the scale of its operations (Avkiran, 1999). Banker et al. (1984) developed the BCC model, which is an extension of the CCR model (Alvandi et al., 2013), which accommodates VRS that implies a disproportionate rise or fall in outputs when inputs are increased, or in other words, if a scenario grows in size, its efficiency will not remain constant, but it will either rise or fall (Avkiran, 1999). When using the VRS approach, the degree of scale efficiency should be estimated, i.e. where a scenario is too small in its scale operations, which falls within the increasing return to scale (irs) part of the production function, and a scenario is too large if it falls within the decreasing return to scale (drs) part of the production function. These inefficient scenarios can be improved by keeping the same input mix, but changing the size of operations (Coelli et al., 2005; Theunissen, 2012).

The purpose of the study is to determine the technical and scale efficiencies of the income statement-based and balance sheet-based DEA models. Using both the CRS and VRS approaches, technical and scale efficiency can be determined, respectively. The following represents a DEA input-orientated view whether a DMU operates on the efficiency frontier, where one of the $n$ DMUs under review and $x_{i 0}$ and $y_{r 0}$ are the $i$ th input and $r$ th output for $D M U_{0}$, respectively.

$\min \theta-\varepsilon\left(\sum_{i=1}^{m} s_{i}^{-}+\sum_{r=1}^{s} s_{r}^{+}\right)$ 


\section{Subject to}

CRS

$\sum_{j=1}^{n} \lambda_{j} x_{i j}+s_{i}^{-}=\theta x_{i 0} \quad i=1,2, \ldots, m$;

$\sum_{j=1}^{n} \lambda_{j} y_{r j}-s_{r}^{+}=y_{r 0} \quad r=1,2, \ldots, s ;$

$\sum_{j=1}^{n} \lambda_{j}=1$

$\lambda_{j} \geq 0 \quad j=1,2, \ldots n$.

$\operatorname{VRS} \operatorname{Add} \sum_{j=1}^{n} \lambda_{j}=1$

Source: Zhu (2009)

The non-zero optimal $\lambda_{j}$ represents the benchmarks for the specific DMU under evaluation. The reference set provides coefficients $\left(\lambda_{j}\right)$ to form the hypothetical efficient DMU. The reference set shows how inputs can be decreased and outputs increased to make the DMU under evaluation efficient. The input-orientated formula calculates input minimization (where $\theta$ indicates the efficiency score). Each observation, $D M U_{j}(j=1, \ldots, n)$, uses $m$ inputs $X_{i j}(\mathrm{i}=1,2, \ldots, m)$ to produce $s$ outputs $\mathrm{Y}_{\mathrm{rj}}(r=1,2, \ldots, s)$, and where $D M U_{o}$ represents one of the $n D M U \mathrm{~s}$ under evaluation, and $X_{i o}$ and $Y_{r o}$ are the $i$ th input and $r$ th output for $D M U_{o}$, respectively. In order to consider any slacks, the presence of the non-Archimedean $\varepsilon$ effectively allows the minimization over $\theta$ to pre-empt the optimization involving the slacks, $s_{i}{ }^{-}$and $s_{r}{ }^{+}$. [For a more detailed discussion on the DEA methodology, see Zhu (2009); Coelli et al. (2005) and Theunissen (2012).]

\section{Hypothesis}

It was argued that companies are probably not performing equally from an income statement perspective versus a balance sheet perspective. Nevertheless, these two financial statements are linked to each other since both of them are performance measures, indicating how well a firm's management is doing without any market-based interference. Therefore, the conceptual framework of the study is that both the income statement-based and balance sheet-based models are performance measures and, therefore, the study hypothesized that that there should be no mean difference, and a positive relationship between the technical and scale efficiencies of the two DEA models, respectively. Within this framework, the following null-hypotheses will be tested:

$\mathbf{H}_{1}$ : There is no mean difference between the technical/scale efficiencies of the income statement-based DEA model and the balance sheet-based DEA model.

$\mathbf{H}_{2}$ : There is no relationship between the technical/scale efficiencies of the income statement-based DEA model and the balance sheet-based DEA model.

\section{METHOD}

This study follows the route of analytical research, which is based on quantitative data (Mouton, 2011). The study can also be classified as ontological research because it involves the study of reality and the generation of knowledge regarding the nature of being, because it attempts to fill a gap in existing knowledge by providing greater insight into a specific area of knowledge (Terre Blanche et al., 2008). Furthermore, inductive reasoning is applied, but since only a small convenient sample is used to test the hypothesis, the generalization of the findings is seriously limited (Mouton, 2011). Nevertheless, the aim of the study is much more a case of developing a balance sheet-based 
and an income statement-based DEA model and to gain some exploratory insight into the differences between the performances measured by the models.

\section{DEA Model}

For purpose of this study, DEA models are created based on the literature. Regarding the input variables for the income statement-based model, following Frijns et al. (2012), expenses are broken up into cost of goods sold (COGS) $\left(\mathrm{x}_{1}\right)$ and other expenses $\left(\mathrm{x}_{2}\right)$. Following Ho and Oh (2010), Lo and Lu (2006), Luo (2003) and Seinford and Zhu (1999), revenue, in the form of turnover $\left(\mathrm{y}_{1}\right)$ and profit, is chosen for the output variables. Following Oberholzer (2012b), to take liquidity into account, EBITDA $\left(\mathrm{y}_{2}\right)$ is chosen as the profit indicator, since it is also some kind of indication of the liquidity of a firm. The rationale of this model is that it measures the efficiency of how all expenditures are converted into revenue and profits. Regarding the input variables for the balance sheetbased model, following Oberholzer (2012a), Lo and Lu (2006), Luo (2003) and Seinford and Zhu (1999), Equity at book value $\mathrm{t}_{\mathrm{t}-1}\left(\mathrm{x}_{1}\right)$ and total assets $\mathrm{t}_{\mathrm{t}-1}\left(\mathrm{x}_{2}\right)$ are chosen for input variables. This combination of inputs also represents leverage as required by Edirisinghe and Zhang (2007; 2010). Following the requirement of growth set by Edirisinghe and Zhang $(2007 ; 2010)$ and combined with the practice of Alvandi et al. (2013) and Oberholzer (2012a), the first output variable is equity at book value $\mathrm{t}_{\mathrm{t}}+$ dividends declared $\left(\mathrm{y}_{1}\right)$ and the second variable total $\operatorname{assets}_{\mathrm{t}}\left(\mathrm{y}_{2}\right)$. Note that some companies do not declare dividends and prefer to reinvest profits; therefore, dividends declared are incorporated in equity. The rationale behind the balance sheet-based model is that it measures the efficiency of growth in assets and shareholders' wealth (equity growth plus dividends).

\section{Sample and Data}

To test the hypotheses, a sample of 51 JSE-listed industrial companies was selected (See Appendix for alphabetical list). Structure differences between sectors, such as industrials, minerals and financials urged that companies from only a single sector are selected. Data were extracted from the McGregor BFA (2013) database. All the companies in the industrial sector, with complete income statement and balance sheet data that did not have year-end date changes, were selected. At the time of data extraction, the latest three-year period ended on 28 February 2013. Therefore, data were analyzed for the three years ended 28 February 2011, 2012 and 2013 (indicated as 2010/11, 2011/12 and 2012/13). However, four years' data were needed for the three years under examination, because the opening balances of book value of equity and total assets $(t-1)$ were used as input variables and the year-end balances $(\mathrm{t})$ were used as output variables.

Table 1 provides a summary of the data used for the different variables. These descriptive statistics clearly indicate the variety in the data. In all cases, the mean value is larger than the median, implying a 'tail' to the left.

Table 1: Descriptive Statistics of Variables in Rand* $(n=51)$

\begin{tabular}{|l|llllllll|}
\hline & Assets $_{\mathbf{t}-\mathbf{1}}$ & Equity $_{\mathbf{t}-\mathbf{1}}$ & Assets $_{\mathbf{t}}$ & $\begin{array}{c}\text { Equity }_{\mathbf{t}}+ \\
\text { dividend }^{-}\end{array}$ & COGS & $\begin{array}{c}\text { Other } \\
\text { expenses }\end{array}$ & Turnover & EBITDA \\
\hline Mean & 6141027 & 2422589 & 6757318 & 3015337 & 8196497 & 472104 & 10150747 & 905518 \\
Median & 1770690 & 909333 & 2014641 & 950560 & 1568580 & 132688 & 2430111 & 188530 \\
Standard Deviation & 9428090 & 3688859 & 10476237 & 4638076 & 17044212 & 798933 & 20705452 & 1577082 \\
Minimum & 166668 & 102464 & 203474 & 124639 & 91145 & 11031 & 164617 & 15359 \\
Maximum & 43219741 & 16715852 & 49023328 & 22559230 & 95650291 & 3716546 & 120601859 & 8099659 \\
\hline
\end{tabular}

Source: Own calculations based on data from McGregor BFA. * South African currency

\section{Hypotheses Tests}

To determine the mean differences $\left(\mathrm{H}_{1}\right)$ between the efficiencies according to the balance sheet-based and income statement-based DEA models, Wilcoxon's signed-ranked test is used because it cannot be assumed (see Table 1) that the data have a normal distribution. The Wilcoxon signed-ranked test is a non-parametric test, similar to the t-test, when two variables are compared in a single sample. Since this test is based on ranks, it is less sensitive to outliers (Maree, 2011). 
To determine the relationship $\left(\mathrm{H}_{2}\right)$ between the efficiencies according to the balance sheet-based and income statement-based DEA models, Pearson's correlation coefficient is used to measure the strength of linear association between these two variables. Note that, in case of a low correlation between the variables, it does not imply that the variables are unrelated. It indicates only that the relationship is poorly described by a straight line and it is possible that a non-linear relationship may exist (Wegner, 2007). Since normality is a prerequisite for linear regression analysis, Spearman's correlation was also used to determine the degree to which the efficiencies of the income statement-based DEA model changes if there is a change in the balance sheet-based DEA model and vice versa. The rank order correlation of Spearman may be used to determine whether there is a monotone dependence between the efficiencies in the two models. Rank order correlation is a non-parametric technique to qualify the relationship between two variables, which means that the correlation statistics are not affected by the type of mathematical relationship between variables. The Spearman rank order correlation coefficient is a more general measure of any kind of monotonic relationship between the dependent and independent variables. This measure is based on ranks and therefore not as sensitive to outliers (Millard \& Neerchal, 2001).

\section{RESULTS}

The software, purposefully developed by Zhu (2009), was used to calculate the input-orientated technical efficiency and scale efficiency estimates. Table 2 exhibits a summary of the results of the technical efficiencies according to both the VRS and CRS approaches and the scale efficiencies (SE) for the three years under review. (Note that the efficiency scores vary between 0 and 1, where 1 indicates that a firm (DMU) is fully efficient.)

Table 2: Technical and Scale Efficiencies for Balance Sheet-Based and Income Statement-Based DEA Models $(n=51)$

\begin{tabular}{|c|c|c|c|c|c|c|c|c|c|c|c|c|}
\hline & \multicolumn{3}{|c|}{$2012 / 13$} & \multicolumn{3}{|c|}{ 2011/12 } & \multicolumn{3}{|c|}{ 2010/11 } & \multicolumn{3}{|c|}{ Average } \\
\hline \multicolumn{13}{|c|}{ Balance Sheet-Based Model } \\
\hline & VRS & CRS & SE & VRS & CRS & SE & VRS & CRS & SE & VRS & CRS & SE \\
\hline Min. & 0.236 & 0.208 & 0.287 & 0.539 & 0.528 & 0.656 & 0.407 & 0.395 & 0.832 & 0.578 & 0.483 & 0.593 \\
\hline Max. & 1.000 & 1.000 & 1.000 & 1.000 & 1.000 & 1.000 & 1.000 & 1.000 & 1.000 & 1.000 & 0.930 & 0.996 \\
\hline Avg. & 0.569 & 0.356 & 0.687 & 0.818 & 0.758 & 0.932 & 0.867 & 0.824 & 0.952 & 0.751 & 0.646 & 0.857 \\
\hline \multicolumn{13}{|c|}{ Income Statement-Based Model } \\
\hline & VRS & CRS & SE & VRS & CRS & SE & VRS & CRS & SE & VRS & CRS & SE \\
\hline Min. & 0.616 & 0.557 & 0.709 & 0.515 & 0.515 & 0.742 & 0.527 & 0.525 & 0.598 & 0.617 & 0.556 & 0.694 \\
\hline Max. & 1.000 & 1.000 & 1.000 & 1.000 & 1.000 & 1.000 & 1.000 & 1.000 & 1.000 & 1.000 & 1.000 & 1.000 \\
\hline Avg. & 0.871 & 0.809 & 0.929 & 0.860 & 0.802 & 0.934 & 0.865 & 0.809 & 0.939 & 0.865 & 0.807 & 0.934 \\
\hline Sig. & $*$ & $*$ & $*$ & $*$ & $*$ & & & & & $*$ & $*$ & . \\
\hline
\end{tabular}

* Significant at 5\% (two-tailed). Source: Own calculations based on data from McGregor BFA

The primary aim of Table 2 is to reveal the differences in the results of the balance sheet-based and the income statement-based DEA models. On average, for the three years, the technical efficiency according the VRS approach is 0.751 for the balance sheet-based DEA model. That implies that these companies should, on average, decrease their inputs by 24.9 percent to become fully efficient. Regarding the three individual years, the opening balances of total assets and total equity should be decreased by 43.1 percent $(1-0.569), 18.2$ percent $(1-0.818)$ and 13.3 percent $(1-0.867)$ for years 2012/13, 2011/12 and 2010/11, respectively, without decreasing the closing balances and dividends. On average, for the three years, the technical efficiency according the VRS approach is 0.865 for the income statement-based DEA model. That implies that these companies should, on average, decrease their inputs by 13.5 percent to become fully efficient. Regarding the three individual years, the cost of goods sold and other expenses should be decreased by 12.9 percent $(1-0.871), 14.0$ percent $(1-0.860)$ and 13.5 percent $(1-$ 0.865) for years 2012/13, 2011/12 and 2010/11, respectively, without decreasing turnover and EBITDA.

The input-orientated technical efficiency, according to the CRS approach, indicates the overall aggregated efficiency. Although the CRS approach is based on the assumption that firms are able to linearly scale their inputs and outputs without changing their efficiency, its value is that it helped to arrive at the conclusion that 43 and 38 companies (not shown in the table) did not achieve economies of scale in the balance sheet and income statement models, respectively. The average scale efficiency scores in Table 2 for the three years under review of 0.857 and 0.934 of the balance sheet and income statement models imply that companies should on average reduce inputs, over and above the VRS technical efficiency improvements, by another 14.3 percent and 6.6 percent, respectively, to become fully efficient and operating on the CRS frontier. 
Table 2 exhibits the mean differences between the balance sheet-based and income statement-based efficiencies. Wilcoxon's signed-ranked test was based on the significant level, where $\rho<\alpha=0.05$ (two-tailed), implying that there is strong evidence that the null-hypothesis should be rejected in favor of the alternative hypothesis. Where $\mathrm{p}>\alpha=0.05$ the null-hypothesis will not be rejected since there is weak or no evidence to accept the alternative hypothesis (Wegner, 2007). The first null-hypothesis $\left(\mathrm{H}_{1}\right)$ of the study states that there is no mean difference between the technical/scale efficiencies of the income statement-based DEA model and the balance sheetbased DEA model. The null-hypothesis is rejected for all three efficiency measures in 2013/2012, VRS and CRS technical efficiency in 2011/12 and all three efficiency measures for the averages of the three years under review.

Table 3: Pearson and Spearman Correlation Coefficients: Balance Sheet-Based and Income Statement-Based DEA Models $(\mathbf{n}=51)$

\begin{tabular}{|l|ccc|cccc|ccc|ccc|}
\hline & \multicolumn{3}{|c|}{$\mathbf{2 0 1 3 / 1 2}$} & & \multicolumn{3}{c|}{$\mathbf{2 0 1 2} / \mathbf{1 1}$} & \multicolumn{3}{c|}{$\mathbf{2 0 1 0} / 11$} & \multicolumn{3}{c|}{ Average } \\
\hline & VRS & CRS & SE & VRS & CRS & SE & VRS & CRS & SE & VRS & CRS & SE \\
Pearson & 0.273 & 0.214 & 0.077 & 0.327 & 0.257 & 0.566 & 0.390 & 0.412 & 0.468 & 0.433 & 0.417 & 0.329 \\
p-value & 0.053 & 0.132 & 0.591 & 0.019 & 0.068 & 0.000 & 0.005 & 0.003 & 0.001 & 0.002 & 0.002 & 0.018 \\
& & & & $*$ & & $*$ & $*$ & $*$ & $*$ & $*$ & $*$ & $*$ \\
Spearman & 0.272 & 0.459 & 0.105 & 0.318 & 0.256 & 0.446 & 0.421 & 0.429 & 0.448 & 0.408 & 0.435 & 0.130 \\
p-value & 0.053 & 0.001 & 0.464 & 0.023 & 0.069 & 0.001 & 0.002 & 0.002 & 0.001 & 0.003 & 0.001 & 0.362 \\
& & $*$ & & $*$ & & $*$ & $*$ & $*$ & $*$ & $*$ & $*$ & \\
\hline
\end{tabular}

* Significant at 5\% (two-tailed). Source: Own calculations based on data from McGregor BFA

Table 3 exhibits the Pearson and Spearman correlation coefficients between the balance sheet-based and income statement-based efficiencies. The correlation coefficients were also based on the significance level, where $\rho$ $<\alpha=0.05$ (two-tailed). The second null-hypothesis $\left(\mathrm{H}_{2}\right)$ of the study states that there is no relationship between the technical/scale efficiencies of the income statement-based DEA model and the balance sheet-based DEA model. The null-hypothesis is rejected according to both Pearson and Spearman's correlation coefficients for all three efficiencies in 2010/2011, VRS technical efficiency and scale efficiency in 2011/12 and only according to Spearman's correlation coefficient for the CRS technical efficiency in 2012/13. On average, the null-hypothesis should be rejected in favor of the alternative hypothesis in all cases except for scale efficiency, according to the Spearman's correlation coefficient.

\section{CONCLUSION}

The purpose of the study was firstly to explore previous literature to create an income statement-based and a balance sheet-based DEA model, and secondly, to demonstrate the models on JSE listed companies and to compare the technical and scale efficiencies of firms between the two models. Data for the years ended 28 February 2013, 2012 and 2011 of 51 industrial firms were analyzed to demonstrate the models. The null-hypotheses of the study state there is, for $\mathrm{H}_{1}$, no mean differences, and for $\mathrm{H}_{2}$ no relationship between the technical (VRS and CRS approaches) / scale efficiencies of the income statement-based DEA model and the balance sheet-based DEA model.

The study firstly found for the three years under review that the first null-hypothesis $\left(\mathrm{H}_{1}\right)$ is rejected four times out of a possible six for VRS and CRS technical efficiencies, and, on average, both are rejected the nullhypothesis (Table 2). This implies that the mean efficiencies of converting expenses (cost of goods sold and other expenses) into turnover and cash profit (EBITDA) are mostly significantly higher than the mean efficiencies of converting assets and equity into asset and equity growth and dividends. Therefore, the study concludes that firms are not equally performing from an income statement perspective versus a balance sheet perspective, meaning that these firms generally find it easier to operate on the efficiency frontier for income statement performance as in the case of balance sheet performance. Regarding the scale efficiency, the study is inconclusive, since the nullhypothesis is not rejected in two of the three years and rejected only in one year and for the average of the three years (Table 2). The study found for the three years under review and for the average that the second null-hypothesis $\left(\mathrm{H}_{2}\right)$ is rejected 11 times out of a possible 16 for the VRS and CRS technical efficiency, and it is rejected five times out of a possible eight for scale efficiency (Table 3 ). The conclusion is therefore that there is some evidence (16 out of 24) that when the income statement-based performance changes, there is also a change in the balance sheet performance, and vice versa. 
The contribution of this ontological study is that it fills the gap in existing knowledge by providing greater insight that corporate managers can become conscious that, although the income statement and balance sheet performances tend to be related, there is evidence of a significant gap between firms performance according to these measurements. The practical value is that the management of firms tends to find it easier to operate closer to the efficiency frontier with regard to the income statement measures and that more improvement is required with regard to their balance sheet performances. The value of the study is that this is the first attempt to create separate DEA models to evaluate and compare the income statement and balance sheet performances for non-banking firms. The limitation of this study is that the study was only exploratory in nature and the results are only valid for the firms in the sample and that the results cannot be widely generalized. Therefore, future studies should be conducted to determine whether there is a difference between the income statement and balance sheet performances of firms in different sectors.

\section{AUTHOR INFORMATION}

Professor Merwe Oberholzer is currently Professor in the School of Accounting Sciences at the North-West University (South Africa). He has taught extensively in the Chartered Accountancy and Chartered Management Accountancy programs. His academic research output includes more than 40 peer-reviewed articles and conference presentations. His current research focuses on performance management, corporate resilience and sustainability. E-mail: Merwe.Oberholzer@nwu.ac.za

\section{REFERENCES}

1. Alvandi, M., Fazli, S. \& HashemiSiavoshani, A. (2013). Combination Value Investing And Momentum Investing To Stock Selection Using Data Envelopment Analysis. International Research Journal of Applied and Basic Sciences, 4(3): 741-746.

2. Anderson, T. (1996). A Data Envelopment Analysis (DEA) Homepage. Retrieved from: http://www.emp.pdx.edu.dea/homedea.html/

3. Arnott, R.D. \& Asness, C.S. (2003). Surprise! Higher Dividends = Higher Earnings Growth. Financial Analysts Journal, 59(1): 70-87.

4. Avkiran, N. (1999). An Application Reference For Data Envelopment Analysis In Branch Banking: Helping The Novice Researcher. International Journal of Bank Marketing, 17(5): 206-220.

5. Banker, R.D., Charnes, A. \& Cooper, W.W. (1984). Some Models For Estimating Technical And Scale Efficiencies In Data Envelopment Analysis. Management Science, 30(9): 1078-1092.

6. Charnes, A., Cooper, W.W. \& Rhodes, E. (1978). Measuring Efficiency Of Decision-Making Units. European Journal of Operations Research, 2: 429-444.

7. Chen, T. (2002). Measuring Firm Performance With DEA And Prior Information In Taiwan's Banks. Applied Economic Letters, 9(3): 201-204.

8. Coelli, T.J., Rao, D.S.P., O’Donnel, C.J. \& Battese, G.E. (2005). An introduction to efficiency and productivity analysis. New York: Springer.

9. Collins English Dictionary . (2003). Complete and Unabridged. HarperCollins Publishers. Retrieved from: $\leq \mathrm{a}$ href="http://www.thefreedictionary.com/nonparametric+statistics" $>$ nonparametric statistics $</ a>$

10. Correia, C., Flynn, D., Uliana, E. \& Wormald, M. (2011). Financial management, Cape Town: Juta.

11. Edirisinghe, N.C.P. \& Zhang, X. (2007). Generalized DEA Model Of Fundamental Analysis And Its Application To Portfolio Optimization. Journal of Banking \& Finance, 31: 3311-3335. (doi: 10.1016/j.jbankfin.2007.04.008).

12. Edirisinghe, N.C.P. \& Zhang, X. (2010). Input/ Output Selection In DEA Under Expert Information, With Application To Financial Markets. European Journal of Operational Research, 207: 1669-1678. (doi:10.1016/j.ejor.2010.06.027).

13. Frijns, B., Margaritis, D. \& Psillaki, M. (2012). Firm Efficiency And Stock Returns. J Prod Anal, 37: 295306. (DOI 19.1007/s11123-011-0246-y).

14. Gattoufi, S., Wang, Y., Reisman, A. \& Oral, M. (2007). An Interpretation Of The Technical Efficiency As The "Best Possible Deviation" From The Conditions Defined By The Weak Axiom Of Profit Maximization. International Business \& Economic Research Journal. The Clute Institute. Retrieved from: http://journals.cluteonline.com/index.php/IBER/article/view/3344/3391 
15. Hassan Al-Tamimi, H.A. \& Lootah, A.M. (2007). Evaluating The Operational And Profitability Efficiency Of A UAE-Based Commercial Bank. Journal of Financial Services Marketing, 11(4): 333-348.

16. Ho, C-T.B. \& Oh, K.B. (2010). Selecting Internet Stocks Using A Combined DEA And AHP Approach. International Journal of System Science, 41(3): 325-336.

17. Ho, C-T.B., Wu, D.D., Chou, C. \& Olson, D.L. (2009). A Risk Scoring Model And Application To Measuring Internet Stock Performance. International Journal of Information Technology and Decision Making, 8(1): 133-149.

18. Liu, S-T. \& Wang, R-T. (2009). Efficiency Measures Of PCB Manufacturing Firms Using Rational TwoStage Data Envelopment Analysis. Expert Systems with Application, 36: 4935-4939.

19. Lo, S.F. \& Lu, W.M. (2006). Does Size Matter? Finding The Profitability And Marketability Benchmark Of Financial Holding Companies. Journal of Operational Research, 23(2): 229-246.

20. Luo, X. (2003). Evaluating The Profitability And Marketability Efficiency Of Large Banks: An Application Of Data Envelopment Analysis. Journal of Business Research, 56: 627-635.

21. Maree, K. (Editor). (2011). First steps in research. Pretoria: Van Schaik.

22. McGregor BFA. (2013). Database. Retrieved from: http://mcgregorbfa.co.za.

23. Millard, S.P. \& Neerchal, H.K. (2001). Environmental statistics with S-plus. Boa Raton, Florida: CRC Press.

24. Min, H., Min, H., Joo, S.J. \& Kim, J. (2009). Evaluating The Financial Performance Of Korean Luxury Hotels Using Data Envelopment Analysis. The Service Industries Journal, 29(6): 835-845.

25. Mouton, J. (2011). How to succeed in your master's and doctoral studies. Pretoria: Van Schaik.

26. Munksgaard, J., Wier, M., Lenzen, M. \& Dey, C. (2005). Using Input-Output Analysis To Measure The Environmental Pressure Of Usage Of Different Spatial Levels. Journal of Industrial Ecology, 9(1-2): 169185 .

27. Murthy, D.S., Sudha M., Hegde, M.R. \& Dakshinamoothy V. (2009). Technical Efficiency And Its Determinants In Tomato Production In Karnataka, India: Data Envelopment (DEA) Approach. Agricultural Economics Research Review, 22: 215-224.

28. Myburg, J.E., Fouché, J.P. \& Cloete, M. (2011). Accounting: An introduction. Durban: LexisNexis.

29. Oberholzer, M., Van der Westhuizen, G. \& Van Rooyen, S. (2010). The Influence Of Banks' Internal Performance On Market Performance: A Non-Parametric Approach. Southern African Business Review, 14(2): 65-88.

30. Oberholzer, M. (2012a). The Relative Importance Of Financial Ratios In The Creation Of Shareholders' Wealth. South African Journal of Economic and Management Sciences, 15(4): 416-428.

31. Oberholzer, M. (2012b). The Efficiency Of South African Mining Companies To Create Shareholder And Stakeholder Value From Environmental Exploitation. Studia UBB Oeconomica, 57(2): 70-82.

32. Ray, S.C. (2004). Data envelopment analysis: Theory and techniques for economics and operational research. Cambridge University Press: Cambridge.

33. Seinford, L.M. \& Zhu, J. (1999). Profitability And Marketability Of The Top 55 US Commercial Banks. Management Science, 45(9): 1270-1288.

34. Short, D.G., Libby, R., Libby, P.A. \& Giullian, M.A. (2011). Financial accounting. New York: McGrawHill/Irwin.

35. Tchereni, B.H.M., Ngalawa, H.P.E. \& Sekhampu, T.J. (2012). Technical Efficiency Of Smallholder Sugarcane Farmers In Malawi: The Case Of Kasinthula Cane Growing Sceme. Studia UBB Oeconomica, 57(2): 3-13.

36. Terre Blanche, M., Durrheim, K. \& Painter, D. (Editors). (2008). Research in practice: Applied methods for the social sciences. Cape Town: University of Cape Town Press.

37. Theunissen, M. (2012). An application of Data Envelopment Analysis to benchmark CEO remuneration. MCom mini-dissertation, North-West University: Potchefstroom.

38. Wang, R-T., Ho, S-T.B. \& Oh, K. (2010). Measuring Production And Marketing Efficiency Using Grey Relation Analysis And Data Envelopment Analysis. International Journal of Production Research, 48(1): 183-199.

39. Wegner, T. (2007). Applied business statistics: Methods and Excel-based applications. Cape Town: Juta.

40. Zhu, J. (2009). Quantitative models for performance evaluation and benchmarking: Data envelopment with spreadsheets and DEA Excel Solver. New York: Springer. 


\section{APPENDIX}

Adcorp
Afrimat
Altron
Amecor
Arb
Argent
Astrapak
Austro
Aveng
Barloworld
Basread
Bell
Bidvest
Bowcalf
Calgro
Control
Dawn
Digicor
Elb
Ellies
Eqstra
Esrofrank
Grindrod
Group5
Howden
Hudaco
Illiad
Imperial
Invicta
Kap
Kayday
Kelly
M\&R
Masonite
Mazor
Metrofile
Micromega
Mixtel
Morvest
Nampak
PPC
Protech
Raubex
Reunert
S.Ocean
Santova
Supergroup
Transpaco
Trencor
Value
WBO


NOTES 